\title{
Half-century of Sociopolitical Transformations in Yemen in Habib Saruri's Columnist Style Novels
}

\section{N. Suvorov}

St. Petersburg State University, 7-9, Universitetskaya nab., St. Petersburg, 199034, Russian Federation

For citation: Suvorov M.N. Half-century of Sociopolitical Transformations in Yemen in Habib Saruri's Columnist Style Novels. Vestnik of Saint Petersburg University. Asian and African Studies, 2020, vol. 12, issue 3, pp. 380-397. https://doi.org/10.21638/spbu13.2020.305

\begin{abstract}
After the unification of North and South Yemen into a single state in 1990, some Yemeni writers tried to rethink in a literary form the country's recent past, which was presented in the literature of the previous period in an ideologically embellished form. One of the first authors to do so was Habib Saruri, a Yemeni-born computer scientist who lives permanently in France. In his first novel, The Ruined Queen (1998), he described the life of South Yemen in the first half of the 1970s, during the period of active implementation of the theory of scientific socialism in the country. The success of the novel encouraged Saruri to continue writing, and to date he has published nine novels. In most of his works, the writer focuses on the sociopolitical transformations that Yemen has gone through over the past half-century, including the socialist experiment of the 1970-80s and the civil war of 1986 in the South, the consequences of this war for the losing side, the process of rapprochement and unification of the two parts of Yemen, the civil war of 1994 in the united Yemen and its consequences for the South, the spread of radical Islamism, the revolution of 2011 and further political chaos, the Houthis' attempt to capture Aden in 2015, and the current military campaign of the Arab coalition against the Houthis. Saruri treats the events of Yemen's modern history boldly and straightforwardly, in a manner characteristic of a columnist, and most of his works resemble journalism, presented in the form of a novel. This article examines the picture of the modern history of Yemen presented in six of Saruri's novels: The Ruined Queen (1998), Damlan (2004), The Bird of Destruction (2005), Suslov's Daughter (2014), The Grandson of Sinbad (2016), and Revelation (2018).
\end{abstract}

Keywords: Arab literature, Arab novel, Yemen, Habib Saruri (Sarori).

The formation of the modern-type literature in Yemen took place against the background of violent revolutionary events in this country in the period between the mid1950s and the late 1960s. These events resulted in the foundation of two independent states: the Yemen Arab Republic (YAR, North Yemen) and the People's Democratic Republic of Yemen (PDRY, South Yemen). The high level of politicization of Yemeni public life during this period, the clash of conflicting interests, views and ideologies, and the armed struggle in the North and South of Yemen - all this produced an ideological bias in Yemeni literature at the stage of its formation. The ruling regimes of the two Yemeni states - conservatively traditionalistic in the North and radical-leftist in the South were not interested (each for its own reason) in creating an atmosphere of freedom of thought and speech in their countries. For this reason, over the next two decades, the lite-

() Санкт-Петербургский государственный университет, 2020 
rary works of Yemenis remained clamped (especially in PDRY) in the grip of censorship that fought the spread of views that contradicted the views of the state authorities.

The revolutions of 1962 in the North and 1963 in the South became symbols of the transition from oppression to freedom, from darkness to light. The concept of the "achievements of the revolution" has become the main element of political rhetoric at all levels of public life in both states. The events of the revolutionary period and the subsequent national state-building were being presented in literature in an exclusively romantic, heroic light. Other interpretations of these events were not actually allowed.

In the PDRY, for example, the authors were expected to write about "class struggle", which in its classical Marxist sense did not exist in Yemen. Writing about something that didn't exist was, of course, difficult. Therefore, the class struggle in literature took the form of traditional, understandable conflicts (land-conflicts or bride-conflicts) - but between the characters, whom the author attributed to antagonistic classes and artlessly endowed with opposite personal qualities. Thus, the template pair of antagonists in these works was presented by an insidious "feudal oppressor" in the face of a sheikh or sultan and an enlightened, virtuous, revolutionary-minded young man, who also possessed the "class consciousness". The process of the formation of the young man's class consciousness was portrayed in an extremely unconvincing way, or even remained outside the scope of the story. Sheikhs and sultans seemed even more implausible in the role of tyrants, since in reality they were representatives of the families, traditionally esteemed for their nobility and sense of justice. As a result of all this, many South Yemeni literary works of the time were no more than ideological "fairy tales".

Only after the unification of the two parts of Yemen into a single state (the Republic of Yemen) in 1990, censorship restrictions were largely eliminated, which allowed Yemeni writers to present in their works a more objective and more realistic picture of the life of Yemen in the previous 20-30 years.

An alternative picture of the revolution of 1962 in North Yemen and the subsequent civil war was presented in the novels Coffee Flower (Zahrat al-bunn, 1998) by Ali Muhammad Zayd and Another Face of Sanaa (Șanā' al-wajh al-akhar, 2004) by Ibrahim Ishaq [1; 2]. A critical view of the sociopolitical and cultural situation in PDRY appeared for the first time in Yemeni literature in the novels Three Midnighters (Al-Summār al-thalātha, 1993) by Sa 'id Awlaqi and Soaring into the sky (Yā țāli‘ al-faḍā', 1995) by Abdullah Salim Bawazir, both novels combining elements of realism, allegory and fantasy [3; 4]. As for the mere realistic depiction of this situation, it appeared for the first time in the novel The Ruined Queen (Al-Malika al-maghdūra, 1998) by Habib Abd al-Rabb Saruri, which was the first literary work of the author ${ }^{1}[5 ; 6]$. The success of the novel encouraged Saruri to continue writing, and to date he has published nine novels. In almost all of his works, the writer touches in one way or another on the sociopolitical and cultural realities of Yemen in various periods of its recent history. This is what I'm going to discuss in this article.

Habib Saruri was born in 1956 in Sheikh Othman, a suburb of Aden, in the family of a Muslim lawyer, Sufi and poet, who instilled in his son a love of classical Arabic language and classical Arabic poetry. In the early 1970s, after the leftist forces came to power in

1 The novel was written and published in French in 1998, and in 2002 it was published in Arabic translation. 
South Yemen, Habib came under the influence of completely new ideas and slogans that proclaimed building a progressive socialist society in the country. Later, the writer ironically recalled how impressed he was by some of the naive arguments given in Georges Politzer's book A Course on Marxism, and how ridiculous the political rhetoric was, pronounced by semi-literate Party functionaries, who were born and raised up in the wilds of Yemeni provinces. When Habib got an opportunity to go to study in France in 1976, he sincerely hoped to witness the "decline of capitalism" there, as he later wrote about it [7].

The first impressions of France gave Habib a cultural shock. Learning French in the old aristocratic town of Vichy, communicating with students from different countries, a curriculum full of exciting cultural and sightseeing events, absolute freedom of expression of political and religious views, both in everyday human communication and in the media - all this looked like life on another planet for the young Yemeni. The period of study, first in Vichy, then at the University of Rouen, was a stage for Habib Saruri to rethink his youthful views and acquire broad erudition. His passion for French literature, especially French novel, finally turned him into a sincere adherent of the humanitarian values of Western civilization.

After defending his doctoral thesis in 1987 Saruri began teaching computer technology at the University of Rouen, in 1992 he held the position of Professor at the same University, and in 1998 he published his novel The Ruined Queen.

The story, told by a man named Naji, presents his memoirs about his childhood and youth spent in Sheikh Othman in the 1960s and the first half of the 1970s. These memoirs, told in lively, witty language, are particularly interesting because those years marked the beginning of the socialist reformation of the country, that in many cases took tragicomic forms. It is the high degree of documentality and the author's magnificent irony in describing the sociopolitical atmosphere of those years that brought the novel popularity among Yemeni readers.

The novel could have been classified as mere autobiographical fiction (although the author denied the possibility of full identification of his personality with that of the protagonist [8, p.71-72]), if not for the writer's penchant for philosophical interpretation of the sociocultural essence of Yemen. A concentrated expression of this interpretation is contained in an episode that defines the name of the novel, and to which the author returns again and again throughout the story. A chess queen, broken in half by the devout father of young Naji in a fit of dislike for everything new and unconventional, turns in the novel into a symbol of all the victims of the violent, thoughtless and many-sided force, whose power the author considers an immanent feature of social life in Yemen. Naji, his parents, his beloved Ibtihal, his best friend Adnan, and all worthy people in the novel are victims of various manifestations of this force, and Yemen, thus, appears as a kind of Evil Empire, where any manifestation of humanism is suppressed.

It should be mentioned that the fates of the characters of the novel are quite typical for Yemen and similar to the fates of the characters of many other works of Yemeni fiction. Naji emigrates abroad. Ibtihal commits suicide to avoid marriage to a man she doesn't love. Adnan, an extremely gifted man, goes mad and then dies in the civil war of 1986. Naji's father dies of a heart attack when an illiterate soldier deprives him of the manuscripts of poems, to which he has devoted his entire life. Naji's mother dies because she was misdiagnosed in an Aden hospital. The author summarizes this number of deaths in the following passage: 
"To die in Yemen is as easy as to drink water. Death in Yemen is common, everyday, familiar, and ubiquitous. If you don't get a bullet in your head, you'll die for any other reason. Why you should die, doesn't matter. Everyone here knows that 'The sword may excuse you - but death never will. Misfortunes are various — the end is the same"'2 [6, p.210].

The only character in the novel who feels perfectly at home in Yemen at all times is Heshwan, a figure at once comic and sinister. Heshwan is a former shepherd from a mountain village, a semi-literate Party functionary who hammers the principles of "dialectics" and "scientific socialism" into the heads of the inhabitants of Sheikh Othman. Upon the collapse of this very "scientific socialism" in South Yemen, Heshwan appears to be an extremely rich man and a recognized authority on matters of religion. The typicality of such a character in the public life of Yemen far exceeds its symbolism as a literary image, although this image in the novel is the main personification of the violent, thoughtless force that eternally rules the country.

The place occupied by Heshwan in the narrative makes him almost the central figure of the novel. It is his speech and actions that reproduce in the novel the social atmosphere of the 1970s in PDRY.

"He learned by heart all the names," Naji says, "that were indispensable in his new position: Marx, Engels, Lenin, Stalin, Mao, and others... He listed their works, memorized all their titles and dates, and the number of chapters in them. As soon as he finished his political education course, he began to lament ignorance of our elementary school students. He was asking a student, 'Have you read comrade Lenin's One Step Forward, Two Steps Back?' The unfortunate schoolboy replied in a voice trembling with emotion, 'No. If it wasn't for Lenin's name, the kid probably would have thought that it was a book about children's games. Then the poor thing would begin to feel like some prehistoric creature living in an unknown epoch, when Heshwan would put his hand on his forehead in amazement and ask, 'How can you live without learning the works of Lenin?"' [6, p. 159-160].

"While studying in his ideological courses," Naji continues, "Heshwan not only learned all the main names and words in these works' tables of contents, but also discovered the 'Law of being. His sense of self-pride reached a climax when he informed us, in a tone in which Bedouin notes were mixed with the characteristic educational pathos of those years, that 'quantitative changes produce qualitative changes', and that this is the second law of the 'principles of dialectics', following the law of 'struggle of opposites' and preceding the law of 'negation of negation"' [6, p. 162].

"In his 'morning lectures"' Naji goes on, "Heshwan constantly told us that he himself must be, as Lenin taught - or rather, 'my comrade Lenin', as he said, - ten steps ahead of the people. Exactly ten, no more and no less. More than ten is too far, and less than ten is not enough - this explanation we were receiving from the former shepherd, who, when driving a flock of sheep in his childhood, somehow managed without this instruction" [6, p. 189].

The presence of Heshwan and his ideology in practically all spheres of activity of the residents of Sheikh Othman, that gave the district the nickname Heshwan grad (in parallel with Leningrad and Stalingrad), is well illustrated by an episode in which Heshwan scolds Naji for the "petty bourgeoisness" of his youthful note about love that was published in a local newspaper.

2 This and the following citations are translated from Arabic by the author of the article, unless another translator's name is indicated. 
"I have never grown tired of repeating," Heshwan says, "that every word, every letter, every look, every movement, every number and every dot ultimately serves either the cause of the working class and its true allies, or the class enemy. There is no third way. Everyone must decide which side they are on" [6, p. 183].

Heshwan in the novel is just one of the army of Party activists like him who came to Aden from rural provinces in the early 1970s, when South Yemeni politics turned leftwing.

"All of them are absolutely ignorant," Adnan says about these activists, "but they have surprisingly memorized the following phrase, that has led more than one person to join the revolutionary movement, 'When quantitative changes reach a certain point, they lead to qualitative changes'. An example of this is water, that changes from the liquid state to the vaporous state when it reaches a boiling point of one hundred degrees - a revolutionary mark that will make our sleepy city wake up and will irrevocably transport us from the prehistoric era to the bright future, to the earthly Paradise... They are all terribly ignorant, but know very well that this is the second law of the 'principles of dialectics', following the law of 'struggle of opposites' and preceding the law of 'negation of negation"' [6, p. 26-27].

It is also very typical for Yemen that many such activists after the collapse of socialism in the country did the same as Heshwan, who "quickly realized that, in fact, one can save all the main things from his rhetorical baggage and oratorical manner, replacing only some of the components - the revolution for democracy, socialism for the market, the USSR for the United States, - and everything will be as good, thorough and correct as it was before" [6, p.238].

Many episodes in the novel present vivid, almost documentary evidence of everyday life in Aden in the 1970s. Thus, Saruri describes one of the characteristic features of that time - the food deficit caused by governmental measures to nationalize the economy and centralize agricultural production planning.

"At that time, there was no tea, no sugar, no meat, no vegetables on sale," Naji tells the reader, "but important scientific discoveries were made thanks to this. For example, a good-natured host of the radio program 'Man and science' once reported that one egg contains the same amount of nutrients as a kilogram of meat, and this, as if by magic, turned the lack of meat into an 'achievement of the revolution"' [6, p. 136].

"I was going to tell Ibtihal," Naji continues, "that before her family moved to our city, there were shops full of vegetables and fruit, not these huge empty stalls with almost invisible handfuls of stunted carrots on them. Those who were previously engaged in trade preferred to leave their simple occupation, since there were almost no farmers left in the country, who in turn also realized that it was better to change their profession, after the agricultural policies and the agricultural programs were imposed on them. They simply felt that it was worth doing something new, such as becoming a professional Party functionary whose activities had nothing to do with their old occupation. Working as a secretary of a Party cell, or a district committee, or a regional committee was more in keeping with the spirit of the time than the profession of cultivator. Becoming an employee of one of the embassies abroad was more attractive than growing watermelons. Not to mention such popular positions as political instructor in a school or in a kindergarten, or the chairman of the Popular Defense Forces committee of one of the city's districts" [6, p. 136].

The appeals of uncle Mas'ud, a favorite of adults and children, who was on the watch for the arrival of scarce products in Sheikh Othman's stores, are also indicative in this regard: 
"Hey, children! What a joy today! Now you will learn the great news! Real news! So great that you won't believe it! And you certainly aren't able to thank the government's economic policies for that deservedly... Run quickly! Hurry up! Fifteen minutes ago, three bags of bananas arrived in Sheikh Othman! Brought especially for you! To make you joyful and happy! It is ten minutes that they are being sold! Run quickly to the Central food complex!" [6, p. 125].

With a touch of black humor, Saruri writes about the bloody purges carried out in the early 1970s under the slogans of class struggle.

"If anyone benefited from the achievements of the revolution," Naji says, "it was, according to the gossips in Sheikh Othman, Ali-the-chatterbox. It is because the father of his beloved girl in Hadramawt, who refused to marry his daughter to Ali because of the latter's 'low social origin' and who said that such a marriage was impossible while he was alive, left this world. During the memorable 'peasants uprisings' organized by the Party, he was 'laid face down in the mud' and shot dead along with all the others whom the revolution labelled feudalists" [6, p. 144].

In a much more tragic tone, Saruri describes in gruesome detail the civil war of 1986, that claimed tens of thousands of lives and put an end to South Yemeni socialism.

"Who can record the stories of thousands of forgotten victims?" Naji wonders. "Who can write the history of the revolution that devoured its children? Who can read in the eyes of camels the history of a country strangled by war and unconsciousness? Who will be able to keep this memory? Who can explain how such unprecedented atrocities could ever have taken place, anywhere, at any time? Who can explain this insanity? Who can come up with theories to explain this madness? Who can reveal the logic of this madness?" [6, p.237].

In the context of the tragic fate of most of the characters in the novel, the fate of Naji himself, who left Yemen forever, seems happy. Here, perhaps for the first time in Yemeni literature, emigration, that has been one of the main themes of the work of several generations of Yemeni writers, appears not as an eternal tragic necessity, but as a simple and sure way for a Yemeni to find happiness in life. This idea, which is repeated in Saruri's subsequent works and is born, no doubt, of the writer's own stable position in France, seems to be putting an end to the illusions of the possibility of man's happiness in Yemen.

Already in the novel The Ruined Queen one could see a specific author's manner of writing that was closer to the manner of a columnist than to that of a novelist. This manner, which further developed in Saruri's subsequent works, manifests itself, in particular, in an irresistible desire of the writer - sometimes even to the detriment of the plot - to talk about topics that personally interest him, to present a variety of scientific and cultural information, to demonstrate his own erudition in many fields, as well as in his obvious sociopolitical bias and witty satirical language. The protagonist-narrator in most of his novels is a French intellectual of South Yemeni origin, whose thoughts, impressions, and memories dominate the narrative. All other characters, as a rule, are nothing more than marionettes, whose inner world is hidden from the reader, or expressed extremely superficially. The stories themselves often do not look like real stories, but rather a kind of a framework, sometimes quite awkward, on which the author "builds up" his columnist-style arguments, that usually express his critical attitude to Yemeni and generally Arab reality. However, it is possible that it was this columnist-style, straightforward manner of narration that brought Saruri popularity against the writings of many other Yemeni authors who prefer allegories and hints. 
The inability of a man to find personal happiness in Yemen, as follows from the first and all subsequent novels of Saruri, is primarily due to the sociopolitical and cultural backwardness of the country. In his second novel, Damlan (Damlān, 2004), the writer was obviously inclined to blame this backwardness on the political regime that came to power as a result of the unification of Yemen in 1990. The Unification was initially met with national jubilation, but it soon became clear that the slogans of democracy, economic and socio-cultural development, under which the Unification was accomplished, turned out to be a fiction. The new regime, defined by many researchers as the rule of a military-tribal oligarchy, was unable to do anything for the development of the country. Some of the civil society achievements made in PDRY, such as the detribalization and empowerment of women, were undone. The situation was also aggravated by the activities of Islamic fundamentalists who were gaining strength and dragging society towards the medieval state.

The novel Damlan, in which the author tried to put, not to say "squeeze", almost all of his life experience, adding in it, besides, some fantastic storylines, precisely because of this "oversaturation" turned out to be extremely loose in terms of plot and composition. Despite this looseness, the novel very clearly presented two main ideas: the extreme backwardness of Yemen and the plight of Yemeni women. The author returns to these themes with his characteristic straightforwardness and wit again and again throughout the story.

Comparing the degree of freedom enjoyed by women in France and Yemen, the writer speaks first of all about the freedom of expression of love feelings. In Yemen, such freedom is not possible at all.

"All of us," Wijdan, the narrator, says, "representatives of this miserable society, that does not know normal food, clean water, education, justice, modern technology, medicine, power other than power of tribes, progress, decent living conditions, well-being, welfare, any other basic things necessary for human life, are deprived, first of all, of love" [9, p. 101].

"I truly believe," Wijdan says, "that this sick, stunted society will rise to its feet only when the hour of the women's revolution strikes, and the era of women's rule begins" [ 9 , p.64].

Saruri's criticism of the general situation in the united Yemen was in Damlan more severe, than his criticism of the situation in PDRY in The Ruined Queen. The socialist regime, that gave the writer in his youth some hope for social progress, seems to him less evil than the rule of ignorant tribal sheikhs, relying solely on the military power of their clans. The writer uses a funny play on Arabic words, saying that under socialism, the country had a policy of tathwir (derived from the word thawra - revolution), that is, "revolutionizing", and now it again has a policy of tathwir (derived in this case from the word thawr - bull), that is, "bulling" or, better, "turning people into bulls" [9, p. 58-59].

The new regime is personified in the novel in Ja'afar, an ignorant and lazy country guy who began his life as a servant and years later turned into a powerful sheikh by the will of fate. The obvious "marionette" nature of Ja'afar in the novel is not a fault of the author, because it is this marionette type, whose inner world is reduced to the desire to achieve a given set of material goods, that is very characteristic of the traditional tribal society of Yemen. Therefore, the following seemingly parodic description of Ja'afar in his youth, in fact, cannot even be regarded a parody:

"The dream of his life, as he told me a thousand times," Wijdan tells the reader, "was to become a powerful and very rich sheikh, to marry according to the law of God four 
girls, 'one younger than the other', as he said, to have a huge palace filled with servants and retinue, to sleep long in the morning, so that the servants would serve him breakfast in bed, then to bathe in his magnificent marble pool, then to sit down to sumptuous dinner, that would include ribs of suckling lambs in broth, fleshy beef shoulder blades and goulash from the veal rump, and then, in the company of important sheikhs and other rich people, chew $q a t^{3}$ in his guestroom, covered with rich carpets, which by evening would be covered with a thick layer of plucked branches of qat, the cost of each being equal to his current monthly salary, received from the old woman Salma" [9, p. 79].

It is this kind of people, the author says to the reader, that rule Yemen today.

Saruri also blames Yemeni intelligentsia for what is happening in the country.

"That Minister," Wijdan says while telling about his service in the army during the years of socialism, "used to repeat in his speeches various wonderful maxims, like this one, 'When I see the grave of a warrior I kneel down to kiss it and when I see the grave of an intellectual I urinate on it'... When I recollect his words with bitterness today I understand that this brave soldier was at least sincere. After all, the military and tribal sheikhs in power today, whose cultural level is no higher than that of the Minister, and whose attitude to intelligentsia is no more respectful, prefer to urinate on some living intellectuals by forcing them to applaud their rule every day, to extol them in poetic odes, to distribute awards and medals on their behalf, and to serve as a civilized façade that hides the backwardness and savagery of the ruling regime" [9, p. 86-87].

The conformism of Yemeni intelligentsia, whom Saruri calls "Yemeni chameleons", is also mentioned in the following passage:

"When I was eighteen years old," Wijdan says, "I, like most of my friends and acquaintances, became involved in youth, political and revolutionary work, as we called it at the time, accompanied by the anthem 'the feature of the epoch is the collapse of the imperialist camp and the victory of the socialist camp, headed by the Soviet Union' and carried out under the motto 'wipe out the petrodollar monarchies and transfer all the wealth to the peoples. Of course, I could not imagine at the time that the main declaimers of all those slogans from among our leaders would turn today into the main yes-men of all these petrodollar kings and princes" [9, p.60].

Saruri's third novel, The Bird of Destruction (Țā'ir al-kharāb, 2005), became a real indictment of both the ruling regime and the archaic traditions of Yemen. A Yemeni couple living in France, Nashwan and Ilham, have an intimate problem: Ilham is completely frigid and unable to conceive. After ten years of living together, Ilham disappears, and in search of his wife Nashwan goes to Yemen, where he faces the realities of modern Yemeni life: the egregious lawlessness of the authorities, the poverty of the population, child prostitution, etc. The Yemeni impressions of Nashwan, who tells the story, make up the outline of the novel, pushing the intrigue of Ilham's disappearance somewhat to the background.

The writer's arguments in the novel concerning the plight of Yemeni women are clearly "Western" in their nature, not typical of most Yemenis. In particular, Nashwan is inclined to associate his wife's sexual problems with Yemeni cultural traditions:

"The reason for Ilham's aversion to intimate relations, or simply her coldness, was rooted, I believed, in the constraints that reign in Yemeni society on the whole, and especially in the sexual sphere, in the tradition of prohibitions that a Yemeni, and especially a

${ }^{3}$ Qat (Catha edulis) is a plant of light narcotic properties, chewing the leaves of which in the company of friends has long been a kind of social habit in Yemen, the main way of socialization (note by M. Suvorov). 
Yemeni woman, absorbs from childhood along with her mother's milk. I read all the books about this written by Nawal al-Sa'dawi ${ }^{4}$, and I also recalled the opinion of Arthur Rimbaud about our country, which he called "hell for women". I also recollected the words of Karl Marx, who wrote that the level of social progress in any society is determined by how free a woman is in it. In other words, the thermometer that shows the degree of a woman's well-being, development of her personality, her freedom and happiness, simultaneously shows the degree of social progress" [10, p. 55].

Nashwan's rejection of hijab, that returned to use in South Yemen after the collapse of socialism, is also very close to the "Western" perception of this phenomenon:

"Flocks of women are wrapped in black robes and thick niqabs, allowing only their eyes to be seen. Looking at these robes and niqabs, you feel anger, fear, and pain. Some niqabs cover the face completely, along with the eyes, so that the woman risks crashing into the first lamp post on her way or getting hit by a passing car. In this terrible summer's humid heat, you would tear off your cotton t-shirt, and even your own skin - so unbearable is this natural hot juicer, in which the temperature reaches forty degrees in the shade, and the humidity exceeds ninety percent. But these women are wrapped from head to toe in robes, niqabs, face masks and thick black gloves - like polar explorers. Who made them endure this suffering? What sadistic fatwa forced them to maintain such an inhumane lifestyle? To give off that persistent smell, which is a disgusting mixture of decomposing sweat, sour incense and cheap perfume? You feel bitter disappointment: in your youth you always dreamed of the 'women's revolution' that would save this poor, exhausted, helpless country. And now, before your eyes, these women accept slavery and humiliation, not known in the days of primitive man! In a fit of irritation and rejection, I feel like saying 'Damn them! The one who accepts such humiliation is worthy of it!' Then the irritation gradually subsides, the anger softens. You suddenly realize that when you left this city, the women here wore mostly light clothes, the girls went to school with the boys. And now that you're back, they're wrapped up in all this black stuff. What a misfortune! It is ironic to remember that someone once spoke of the 'irreversibility of progress'. He should have said about the irreversibility of the abomination and the irreversibility of the tragedy!" [10, p. 142-143].

Saruri seems to be the first writer who openly encroached on the "sacred cow" of Yemeni official rhetoric - the unification of the country.

"You could, of course, feel infinite joy for your Yemen, which is finally united," Nashwan says, "but in reality you do not have a special love for this unification, that is not unification of civil society, that comes with order, justice, cultural achievements, freedom and progress, but unification of tribal arbitrariness, dressed in the garments of state power, unification of the starvation of the population, corruption, barbarism, violence, qat and prehistoric robes" [10, p. 139].

The very name of the novel is a metaphor for the state of affairs that developed in Yemen after the Unification. This becomes clear from the following passage:

"Yemen, where you arrive on July 17, 2000, is extremely sad, infinitely destitute. It is easy to see the bird of destruction, as big as Yemen itself, soaring in its sky from al-Ghayda in the east of Hadramawt to the mountains of Sanaa and the coast of Tihama in the west. This bird is everywhere, it covers the whole sky. It masterfully paints a picture of destruc-

${ }^{4}$ Nawal al-Sadawi is an Egyptian feminist writer, activist, physician, and psychiatrist. She has written many books on the subject of women in Islam (note by M. Suvorov). 
tion on every inch of Yemen's land, adding new patterns to it every day with zeal and care. This is a rare bird that hates and destroys all good things. Its main task is to eradicate all that is civilized, all that is beautiful, all that is free, all that is pure" [10, p. 140].

In the context of the blatant cultural, social and economic backwardness of Yemen, the writer finds the manner of Muslim preachers' activity outrageous:

"Four loudspeakers, located at a great distance from each other in the central part of the quarter and connected by long wires to the minaret of a neighboring mosque, broadcast prayers and sermons to the entire city. A preacher instructs people in broad daylight. What is he talking about? About hunger? No. About poverty? Also no. About ordinary man, who is robbed and humiliated? About the corruption that has permeated this country from top to bottom? About endless interruptions in water and electricity supply? No! About sex tourism and child prostitution? No! About the world's most miserable health and education systems? About the world's lowest socio-economic development indicators? No! What, then, is he talking about in his sermon? About lipstick! Imagine that! About how to beat your wife properly if she uses lipstick! He advises using a lash. He recommends strikes only in the area located between neck and feet. He does not recommend strikes in the face. What an amazing humanism!" [10, p. 162].

There is a passage in the description of Nashwan's life in France:

"Alice was not offended by my words, because she (like all citizens of France, where for almost a century neither the state nor educational institutions recognize any religion, including Christian) did not hear anything about Hellfire, or simply forgot about this concept, even if she ever heard about it in some conversation outside of school" [10, p. 102].

Comparing the two passages above, it is easy to understand Saruri's attitude to the religious radicalization of Yemeni society and, perhaps, to religiosity in general. In Yemen, where the preacher broadcasts his sermons to the entire city, it is almost impossible to live, and in France, where no one cares about the existence of hell and heaven, everything is done for the good of man.

Religious radicalization of Yemeni society became one of the main themes in Saruris seventh novel, Suslov's Daughter (Ibnat Sūslüf, 2014) ${ }^{5}$. In this novel, the writer combined episodes from the life of Aden in the late 1960s and the first half of the 1970s (already described in Ruined Queen) with a picture of the sociopolitical situation in Yemen from the late 1990s until the beginning of Yemeni revolution of 2011.

The story is told by a man named Amran to an imaginary angel of death, Azrael. The story begins with Amran's Aden memoirs, in which many things echo those described in The Ruined Queen. With a great deal of humor, Amran tells about the "corrective" measures taken by the authorities against Aden prostitutes in order to turn them into "proletariat" in a tomato paste factory, about his own fascination with the theory of "scientific socialism" and the "laws of dialectics", about his failed attempt to teach literacy to akhdam ${ }^{6}$, and how a Party commission determined his social origin - making a choice between the "working class" and "petty bourgeoisie" - by counting the number of spoons in the tavern belonging to his father [16, p. 22-24, 35, 43-44, 60-61].

${ }^{5}$ Between The Bird of Destruction and Suslov's Daughter Saruri published fantastic novels The Sweat of Gods ('Araq al-āliha, 2008) and The Hoopoe's Report (Taqrīr al-hudhud, 2012) and love novel Arwa (Arwā, 2013) [11-13]. The novel Suslov's Daughter was translated into French (by Hana Jaber) and English (by Elisabeth Jaquette) [14-15].

${ }^{6}$ Akhdam - representatives of the lower strata of Yemeni society, Yemeni "untouchables". 
Among these memories is Amran's love for a beautiful girl named Fatin, a daughter of a major Party functionary who, after studying in Moscow, headed the Higher school of Marxism-Leninism in Aden and received a nickname "Suslov"7.

In the mid-1970s, Amran went to study in France and after graduation settled in Paris. There he married a girl of Yemeni origin, but in 1995 she tragically died in a terrorist attack carried out by jihadists in Paris metro.

A year later, Amran for the first time arrives in Sanaa to meet his sister, a former Adeni left-wing activist and now a staunch Salafist. His sister introduces him to a young woman named Amat al-Rahman, a Salafi activist. Amat al-Rahman turns out to be Fatin of his youth, the daughter of "Suslov", and intimate relationship begins between her and Amran.

It is noteworthy that "Suslov" himself, whom Amran met in the first half of the 1990s in Aden, also became a devout person, at least outwardly. This transformation of "Suslov's" personality (similar to what happened in the personality of Heshwan in The Ruined Queen) is not only an expression of Saruri's negative attitude to ideologues of all kinds, but is a reflection of the actual growth of religiosity in the southern part of Yemen after the civil war of 1994. About the consequences of this war Amran says:

"As a result of war, the South was thoroughly looted. Its political, military, and civilian elite were exiled, co-ed schooling immediately ceased, and all traces of civil society were erased. The hijab and niqab became commonplace, and Aden's secular identity was effectively stamped out"8 [16, p. 62-63].

A significant part of the rest of the story is taken up by the monotonous and unlikely description of Amran's relationship with Amat al-Rahman, as well as the Facebook correspondence that Amran keeps under a nickname with Salafists, stating his "enlightening" thoughts (that is, Saruri's thoughts). In this narrative, the author intersperses some expressive details and episodes of the sociopolitical life of Yemen, which, as always, occupy him much more than the main storyline and the inner world of the characters.

Here, for example, is how the author describes a Salafi female demonstration in Sanaa, one of whose organizers is Amat al-Rahman:

"A thousand bodies concealed in black hijabs and niqabs, crowded together in rows, each woman accompanied by a young child: a boy or a girl. (According to Salafi beliefs, 'a woman of faith shouldn't go out into the street by herself'. She needs a mahram - unmarriageable kin - if she's going somewhere where there will be men. Or if she's around other women in public, she needs to be accompanied by a young child.)

The wave of women advanced, carrying signs with slogans I couldn't make sense of: Sharia permits four wives (next to a picture of a hand with the thumb curled towards the palm, waving four fingers, from the index finger to the pinky).

Another slogan: Parliament's draft law prohibiting girls under the age of eighteen from marriage conflicts with the sharia's teachings.

And another: The draft law forbidding violence against women discriminates against the principles of the sharia.

And another: The draft law prohibiting men from beating women violates men's rights, as set forth in the Surah of Women, verse 34.

${ }^{7}$ Mikhail Suslov (1902-1982) was a Soviet statesman during the Cold War, unofficial Chief Ideologue of the Communist Party of the Soviet Union.

8 Translated by Elisabeth Jaquette. 
What was this Quranic verse? 'And those women you fear may rebel: admonish, and abandon them in their beds, and smack them'.

I looked down at the torrent of black flooding the street, and asked myself whether this was a nightmare or reality. The scene was more frightening than a horror film. As a modern man, I had a severe allergy to obscurantists and terrorists. I felt a violent urge to vomit"9 [16, p. 75].

The reader, meanwhile, learns that Amat al-Rahman is a wife of Imam Umar al-Hamdani, a son of Imam Muhammad al-Hamdani. The latter is the spiritual leader of all Salafists in Yemen and the mastermind of al-Qaeda's Yemeni branch. It turns out that Amat al-Rahman hates her husband, who suffers from alcoholism, and he allows her to be away from home in the evenings, so that she does not interfere with his drinking. It also turns out that Amat al-Rahman does not really love Amran, but her father-in-law, Muhammad al-Hamdani, who is her spiritual mentor.

There is a separate story in the novel, devoted to Muhammad al-Hamdani. As a young man, he attended medical school in Beirut, was a philanderer, and wore Elvis Presley's pompadour hairstyle. However, after the first year, he was expelled for failing grades, after which he became close to local Salafists and decided to become a preacher. Upon his return to Yemen, he managed to gain a great reputation among Salafi-minded youth and, with the help of his admirers, took the position of Dean of the Faculty of sharia studies. In addition, he managed to force Yemeni Ministry of Health to grant him a license for treatment of any diseases with the help of the Quran, after which "the staff of hospitals in the countries around Yemen did not stop talking about the influx of his patients ("sacrificial sheep of his healing", as they called them), who were in a semi-dead state" [16, p. 145]. This biography of the Imam suggests that his real prototype is the popular Salafi preacher Abd al-Majid al-Zindani, although the latter also appears in the novel under his own name, with a reference to the method he invented for treating AIDS with the help of the Quran and to the audio recording of grave torments ('adhab al-qabr) that he received [16, p. 192].

The end of the relationship between Amran and Amat al-Rahman coincides chronologically with the first stage of Yemeni revolution, namely the events in Sanaa on March 11-18, 2011. The author describes these events through the mouth of Amran quite vividly and with much detail. Amran's impressions of what he sees are ambiguous: the joy of feeling the unity of different layers of Yemeni society in an effort to overthrow the hated regime is overshadowed by the manifestations of Salafi fanaticism of many protesters. And soon Amran bitterly realizes that the leadership in this revolutionary process is beginning to fall in hands of those who have always been the mainstay of the ruling regime and who cannot give the country anything new ${ }^{10}$.

"The 'country of faith and wisdom"” Amran says, "is rushing towards the abyss that has no bottom: to poverty, corruption, robbery, crazy obscurantist teachings, murder, chaos, sectarian wars, the daily deaths of hundreds of people, to underage girls marriage, to the lawlessness of al-Qaeda and the jihadists - as if the highest goal of the 'national democratic revolution' were the creation of Islamic emirates of Kandahar" [16, p. 199].

Some of the events that followed the 2011 revolution are mentioned in Saruri's eighth novel, The Grandson of Sinbad (Hafīd Sindbād, 2016). The novel is a collage of diverse arguments and memories of Alwan, a French computer scientist of Yemeni origin living in

9 Translated by Elisabeth Jaquette.

${ }^{10}$ Here Saruri obviously means the general Ali Muhsin al-Ahmar and his fellow military men. 
2027, and travel notes of his former classmate Nadir, which Alwan has got at his disposal. The content of the novel gives an impression that the novel was intended by Saruri as a "dump" of his own various life experiences, especially travel experiences, which he failed to "attach" to his other works ${ }^{11}$. In any case, the theme of the recent history of Yemen also finds a place here.

For example, Alwan recalls the guerrilla struggle of South Yemenis against the British in the mid-1960s and the bloody conflict between two political groups of these guerrillas in Aden in 1967:

"The willingness to kill and the love of purges grew with this armed struggle, in which the 'revolutionaries' killed more of those whom they labelled as agents and local rulers than of the British military personnel.

It seems that they addicted to killing so much that the mutual murder within the ranks of "comrades" became a stable habit and passion for them.

Four years of armed struggle waged by two revolutionary groups ended shortly before the independence with two wars between themselves and the elimination of one of them by the other. Those two wars were the beginning of a chain of wars that were to break out in this unfortunate country every subsequent decade" [17, p. 172].

The armed conflict between the two revolutionary groups left Alwan with fear of any war, but the memories of that time simply faded in the face of the horror he experienced in Aden in March 2015 during the Houthis' attempt to capture the city. This is how he describes it:

"On the fifth day of my stay in Aden, at the end of March 2015, hordes of Houthis arrived in this unfortunate city, supported by the personnel of the deposed President's military units located inside and around the city, who remained pawns in the hands of himself, his family, his clan and his supporters" [17, p. 172].

"Tanks are hitting from everywhere, snipers of Houthi militia and regular Houthi army, occupying positions on the roofs of houses, shoot accurately at the head, between the eyes or, less likely, in the spine below the skull. Katyusha volleys destroy private houses and public buildings. The latest rocket launchers sweep away everything, turning Aden into ruins and ashes.

The roar of cannons and rocket launchers doesn't stop for a moment, splitting my head. Compared to it, machine-gun bursts of the war of 1967 are no more than soft romantic music.

The regular army is firing at unarmed people. Violent highlanders die with joy - in the name of an ordinary wacky preacher who was brainwashed in the cave of Marran in Saada ${ }^{12}$ and who tells them that he is a descendant of the Prophet and therefore possesses a divine grace ${ }^{13}$.

Jihadist fighters, adults and teenagers, are irrepressible in their desire to kill and die. The sidewalks and roads are littered with corpses. There are pools of blood everywhere.

${ }^{11}$ Interestingly, some Russian family names in the novel (Babkin, Kazakov) may be found in Saruri's academic profile (http://abdulrab.free.fr/shortCV.htm).

12 The mountainous region of Marran in Saada province is the place where the Houthi movement formed.

13 Saruri is referring to either the late Husayn al-Houthi, the founder of the Houthi movement, or to his brother Abd al-Malik, who now leads the movement. 
The other side is simple guys who took up arms for the first time to protect and liberate their beloved city. A lot of Salafis are fighting on their side, some of them are just boys. They are as irrepressible in their Jihad as the enemy's obscurantists, although they belong to a different religious branch" [17, p. 173-174].

Talking about the constant return of Yemen from peace to another war, Alwan says:

"As for the famous saying of Heraclitus, 'You cannot enter the same river twice', either it is wrong, or Yemen enters stagnant water every time" [17, p. 186].

Finally, much of what was discussed in the above-mentioned Saruri's works, he discusses again in his ninth novel, Revelation (Wahy, 2018). The story is told by a man named Ghassan al-Uthmani, who keeps correspondence with an unknown person, which makes him recollect the days of his youth, when he participated in the failed attempt to build "the new society, the new culture and the new man" in PDRY [18, p. 77-82, 110-123, 143-145]. Here Saruri reproduces in detail the same social realities and the same atmosphere that may be found in the novels The Ruined Queen and Suslov's Daughter, adding to them a story about the anti-religious campaign led in PDRY.There is also an antihero, similar to Heshwan in The Ruined Queen and "Suslov" in Suslov's Daughter, - a high-rank Party functionary Abd al-Qahhar, who was nicknamed Qahharof, in the manner of a Russian family name. Ghassan also talks in detail about the war of 1986, that put an end to the socialist experiment in South Yemen, and about the severe consequences of this war for those South Yemenis who were on the losing side [18, p. 166-172].

"After the signal for the treacherous attack on January 13", Ghassan tells the reader, "a war broke out for which the 'clique' had been preparing for many months, but the 'gang' won it because its forces outweighed.

The insidious attack of the clique, and then the retaliatory brutal purges by the gang (on the sole basis that a man was born, according to the information on his identity card, in the same area as any of the clique's leaders) revealed the hideous tribal and parochial face of those who had previously worn the mask of Marxism-Leninism. That treachery and those purges were not usual ones that can be forgotten. People who seemed to have been connected by close, friendly relationships until the night of the massacre, or rather until its morning, suddenly tore off their masks and began to kill each other with rage and madness.

What the devil helped the clique's supporters, working in this or that institution, to conceal their evil intentions so skillfully, and then capture and shoot dead the supporters of the gang, at the same moment when the first shots were fired at the meeting that began with the thermos of tea ${ }^{14}$ ?" [18, p. 169-170].

"After that," Ghassan goes on, "the experiment with scientific socialism in Yemen ended. All social achievements went to waste, the state of order and law disappeared into oblivion. The Higher school of Marxism-Leninism closed its doors forever and everyone forgot their favorite word 'dialectics'. The ground was ready for the transition from one type of radicalism to another - to the radicalism of Salafism and obscurantism. It was planted by jihadists returning from Afghanistan, who were allied with the worst tyrant who ruled North Yemen and later took over all of Yemen (as a result of the Unification) and then turned its southern part into war booty for himself, his tribe, and his hench-

14 The massacre of January 1986 in Aden was started by a guard who brought a thermos of tea to the meeting-hall of the Party's Central Committee and then opened fire on the members of the Committee (note by M. Suvorov). 
men - especially after the war of 1994, when his army and his tribes took over South Yemen and completely trampled it" [18, p. 170-171].

Ghassan also touches upon the war between the regime and the Houthis in 20042010, the revolution of 2011, and the current military conflict between the Houthis and the Arab coalition [18, p. 210-212].

As if summarizing the sociopolitical transformations that Yemen has undergone over the past fifty years, the writer says:

"The whole public lexicon has changed: the place of 'dialectics', 'superstructure and basis', 'transformation of one's class origin', 'proletarian internationalism'... occupied 'Ansar Allah' (i. e. the companions of the 'wacky preacher'), 'Squads of the followers of Sunna', 'Squads of the followers of Zaynab', 'Squads of Abu Hafs al-Shabwani', groups of 'Soldiers of Jihad', 'Squads of martyrs of Husayn'...' [18, p. 213].

The criticism of the sociopolitical situation in Yemen, in its recent past and in present, realistic depiction of political conflicts, especially armed ones and especially those with inter-confessional bias, criticism of Arabs' cultural and religious traditions from the perspective of the Western conception of human rights in general and women's rights in particular - all these things appear in Yemeni novel not very often. The reason for this is that these things cannot but undermine the "trio of taboos" known in Arabic literature: "sex, religion and politics" [19]. Moreover, an author who decides to touch on these dangerous topics always runs the risk of being accused of either immorality or distortion of historical reality - since the mentality of the population of Arab countries like Yemen is still alien to the idea of "fiction" and tend to perceive the personality of the protagonist as identical to that of the author. As Wajdi al-Ahdal, a popular Yemeni novelist, once wrote, "the Arab mind takes fiction too directly, as if the author were writing a journalistic report or historical research"15.

Nevertheless, there is number of Yemeni writers who are not afraid of touching on these dangerous sociopolitical topics. The civil war of 1986 in PDRY, its consequences for the losing side, the subsequent process of rapprochement and unification of the two parts of Yemen, then the civil war of 1994 in the united Yemen and its consequences for the South - all this forms the historical and sociopolitical background in such Yemeni novels as The Last Qarmatian (Ākhir al-qarāmița, 2003) and Yemen and Seasons of Hell (Al-Yaman wa-fușūl al-jahīm, 2010) by Ahmad al-Sayyad, To No-Man's Land (Khalf alshams, 2012) by Bushra al-Maqtari, and Fruit for the Crows (Fākiha li-l-ghurbān, 2020) by Ahmad Zayn [20-23]. Political hostilities between conservative North and leftist South before the unification form a significant part of the background in Muhammad al-Gharbi Amran's novel Red Manuscript (Muṣhaf ahmar, 2010) [24].

The situation in the united Yemen before the revolution of 2011, characterized by total corruption, the violence on the part of state power structures and armed tribal units, the spread of radical Islamist ideology, the suppression of civil liberties, the blatant female discrimination, the decline in health services and education, and an unprecedented increase in poverty, is reflected in one way or another in the novels Nothing but Love (Hubb laysa illā, 2006) and Submissive Wives ('Aqīlāt, 2009) by Nadiya al-Kawkabani, American Coffee (Qahwa amīrkiyya, 2007) and War under the Skin (Harb taht al-jild, 2010) by

15 Wajdi al-Ahdal's e-mail message to the author of the article, dated April 7, 2020. 
Ahmad Zayn, A Land without Sky (Bilād bilā Samā', 2008) and Happy Land of Intrigues (Arḍ al-mu'āmarāt al-sa'īda, 2018) by Wajdi al-Ahdal, and Saada’s Braids (Jadā’il Șa'da, 2014) by Marwan Al-Ghafuri [25-31] ${ }^{16}$.

As for Habib Saruri, his work in this regard stands somewhat apart for two reasons.

First, as a citizen of France, he is not exposed to any danger that may be caused by possible dissatisfaction with his work from any Yemeni influential forces: the current authorities, former authorities, Islamists of any kind, tribal leaders, etc. Therefore, he does not risk anything when he openly discusses in his novels absolutely all episodes of the recent sociopolitical history of Yemen, which he has sufficient understanding of. With equal irony, he writes about the Party functionaries in PDRY and the lawless regime of Ali Abdullah Saleh, about the spiritual leaders of the Salafis and the spiritual leaders of the Houthis, who now control a large part of North Yemen. As for the realistic depiction of the social atmosphere in the first years of building socialism in PDRY, it is generally found in Yemeni literature only in Saruri's works.

Secondly, sociopolitical transformations in the recent history of Yemen are the main theme that feeds all of Saruri's work and to which he returns in his novels at every opportunity. It can be said that unlike other Yemeni authors who depict the twists of human destinies in the context of the sociopolitical history of Yemen, Sarūrī writes about this history as a columnist, giving his columnistic texts, though, a certain degree of artistry by introducing in them some fictional or semi-fictional characters with their plausible and implausible personal stories.

\section{References}

1. Zayd 'Alī Muhammad. Coffee Flower. Beirut, Dār al-Kunūz al-adabyya, 1998. 368 p. (In Arabic)

2. Isḥāq Ibrāhīm. Another Face of Sanaa. Cairo, Dār al-Hilāl, 2004. 179 p. (In Arabic) Arabic)

3. 'Awlaqī Sa īd. Three Midnighters. Sanaa, Markaz 'Ubādī li-l-dirāsāt wa-l-nashr, 1993. 112 p. (In

4. Bāwazīr 'Abdullāh Sālim. Soaring into the Sky. Sanaa, Markaz 'Ubādī li-l-dirāsāt wa-l-nashr, 1995. 80 p. (In Arabic)

5. Abdulrab Habib. La reine étripée. Paris, L'Harmattan littératures, 1998. 236 p.

6. Sarūrī Habīb. The Ruined Queen. Sanaa, Dār al-Muhājir, 2002. 263 p. (In Arabic)

7. Sarūrī Habīb. Surprise, knots and main lines that formed my literary experience. (ms.) (In Arabic)

8. Sarūrī Ḥabīb. About Yemen, Known and Unknown. Sanaa, Mu'assasat al-'Afîf al-thaqāfiyya, 2005. 171 p. (In Arabic)

9. Sarūrī Habīb. Damlan. Sanaa, Mu'assasat al-'Afîf al-thaqāfiyya, 2004. 467 p. (In Arabic) Arabic)

10. Sarūrī Ḥabīb. The Bird of Destruction. Sanaa, Mu'assasat al-'Afîf al-thaqāfiyya, 2005. 247 p. (In

11. Sarūrī Habīb. The Sweat of Gods. Beirut, Riad El-Rayyes Books S. A. R. L., 2008. 189 p. (In Arabic)

12. Sarūrī Habīb. The Hoopoe’s Report. Beirut, Dār al-'ādāb, 2012. 400 p. (In Arabic)

13. Sarūrī Hiabīb. Arwa. Beirut, Dār al-sāqī, 2013. 286 p. (In Arabic)

14. Sarori Habib Abdulrab. La Fille de Souslov. Paris, Actes Sud, 2017. 192 p.

15. Sarori Habib Abdulrab. Suslov's Daughter. London, Darf Publishers Ltd, 2017. 198 p.

16. Sarūrī Habīb. Suslov's Daughter. Beirut, Dār al-sāqī, 2014. 220 p. (In Arabic)

17. Sarūrī Hiabīb. The Grandson of Sinbad. Beirut, Dār al-sāqī, 2016. 222 p. (In Arabic)

18. Sarūrī Habīb. Revelation. Beirut, Dār al-sāqī, 2018. 255 p. (In Arabic)

19. Jaggi Maya. Is the Arab world ready for a reading revolution? Available at: https://www.theguardian. com/books/booksblog/2010/apr/16/arab-world-reading-revolution (accessed: 25.04.2020).

20. al-Șayyād Aḥmad. The Last Qarmatian. Beirut, Al-Mu'assasa al-'arabiyya li-l-dirāsāt wa-l-nashr, 2004. 219 p. (In Arabic)

${ }^{16}$ For more details about some of these novels see my articles [32-34]. 
21. al-Ṣayyād Ahmad. Yemen and Seasons of Hell. Beirut, Riad El-Rayyes Books S. A. R. L., 2010. 247 p. (In Arabic) Arabic)

22. al-Maqțarī Bushrā. To No-Man’s Land. Casablanca, al-Markaz al-thaqāfī al-'arabī, 2012. 206 p. (In

23. Zayn Ahmad. Fruit for the Crows. Milan, Manshūrāt al-Mutawassiț, 2020. 239 p. (In Arabic)

24. 'Amrān Muhammad al-Gharbī. Red Manuscript. Beirut, Dār al-Kawkab, 2010. 348 p. (In Arabic)

25. al-Kawkabānī Nādiya. Nothing but Love. Cairo, Dār Mīrīt li-l-nashr, 2006. 195 p. (In Arabic)

26. al-Kawkabānī Nādiya. Submissive Wives. Sanaa, Markaz 'Ubādī li-l-dirāsāt wa-l-nashr, 2009. 307 p. (In Arabic)

27. Zayn Ahmad. American Coffee. Casablanca, al-Markaz al-thaqāî̀ al-'arabī, 2007. 160 p. (In Arabic)

28. Zayn Aḥmad. War under the Skin. Beirut, Dār al-ādāb, 2010. 192 p. (In Arabic)

29. al-Ahdal Wajdī. A Land without Sky. Sanaa, Markaz 'Ubādī li-l-dirāsāt wa-l-nashr, 2008. 172 p. (In Arabic)

30. al-Ahdal Wajdī. Happy Land of Intrigues. Beirut, Dār Nawfal, 2018. 310 p. (In Arabic)

31. al-Ghafūrī Marwān. Saada’s Braids. Beirut, Dār al-ādāb, 2014. 239 p. (In Arabic)

32. Suvorov M. New Novels from Yemen: Between Revelation and Epatage. Vestnik of Saint Petersburg University. Ser. 13, 2013, issue 4, pp. 68-78. (In Russian)

33. Suvorov M. Two Novels about the Information War in Yemen on the Eve of the Revolution of 2011. Vestnik of Saint Petersburg University. Ser. 13, 2019, issue 3, pp. 298-310.

34. Suvorov M. Yemen and the Arab World in Wajdi al-Ahdal's novels: from Parody to Realism. Eurasian Arabic Studies, 2020, no. 9, pp. 51-64.

Received: May 03, 2020

Accepted: June 29, 2020

Author's information:

Mikhail N.Suvorov — Dr. Sci. in Philology, Professor; soumike@mail.ru

\title{
Полвека социополитических изменений в Йемене в публицистических романах Хабиба Сарури
}

\author{
М. Н. Суворов \\ Санкт-Петербургский государственный университет, \\ Российская Федерация, 199034, Санкт-Петербург, Университетская наб., 7-9
}

Для цитирования: Suvorov M. N. Half-century of Sociopolitical Transformations in Yemen in Habib Saruri's Columnist Style Novels // Вестник Санкт-Петербургского университета. Востоковедение и африканистика. 2020. Т. 12. Вып. 3. С. 380-397.

https://doi.org/10.21638/spbu13.2020.305

После объединения Северного и Южного Йемена в 1990 г. некоторые йеменские писатели попытались в литературной форме переосмыслить недавнее прошлое страны, представленное в произведениях предыдущего периода в идеологически приукрашенном виде. Одним из первых такую попытку предпринял Хабиб Сарури, ученый йеменского происхождения, постоянно проживающий во Франции. В своем первом романе «Погубленная королева» (1998) он описал жизнь Южного Йемена в первой половине 1970-х годов, в период активной имплементации там теории научного социализма. Успех романа побудил Сарури продолжить литературную деятельность, и на сегодняшний день он опубликовал уже девять романов. Первостепенное внимание в большинстве своих сочинений писатель уделяет тем социополитическим изменениям, которые Йемен пережил за последние полвека. Это социалистический эксперимент 1970-1980-х годов и гражданская война 1986 г. в Южном Йемене, по- 
следствия этой войны для проигравшей стороны, последующий процесс сближения двух частей Йемена и их объединения, гражданская война 1994 г. в объединенном Йемене и ее последствия для Юга, распространение радикального исламизма, революция 2011 г. и последующий политический хаос, хуситская попытка захвата Адена в 2015 г. и нынешняя военная кампания арабской коалиции против хуситов. События новейшей йеменской истории Сарури трактует смело и прямолинейно, в манере, близкой к публицистической, и большинство его произведений можно назвать публицистикой в форме романа. Рассматривается картина новейшей истории Йемена, представленная в шести романах писателя: «Погубленная королева» (1998), «Дамлан» (2004), «Птица разрухи» (2005), «Дочь Суслова» (2014), «Внук Синдбада» (2016), «Откровение» (2018).

Ключевые слова: арабская литература, арабский роман, Йемен, Хабиб Сарури.

Статья поступила в редакцию 3 мая 2020 г., рекомендована к печати 29 июня 2020 г.

Контактная информация:

Суворов Михаил Николаевич — д-р филол. наук, проф.; soumike@mail.ru 